\title{
O silêncio anticolonial de Conrad e Eça, ou a impossível arte de narrar o horror
}

\author{
José Carlos Siqueira
}

Universidade Federal de Ceará

Edward Said, em seu imprescindível Cultura e imperialismo (1993, ed. brasileira de 1995), apresenta a obra-prima de Conrad, O coração das trevas, como o modelo maior da representação positivada do imperialismo europeu no século XIX. Diz o crítico palestino:

Coração das trevas é uma obra que funciona tão bem porque sua política e sua estética são, por assim dizer, imperialistas, as quais, nos últimos anos do século XIX, pareciam ser uma política e uma estética, e até uma epistemologia, inevitáveis e inescapáveis (Said, 1995, p. 56).

Na verdade, todo o livro de Said é um exercício analítico para demonstrar que o romance moderno é a expressão literária do colonialismo europeu dos Oitocentos:

\footnotetext{
A tese de Conrad está inscrita na própria forma narrativa, tal como ele a herdou e a praticou. Eu chegaria a dizer que, sem império, não existe o romance europeu tal como o conhecemos, e na verdade, se estudarmos os impulsos que lhe deram origem, veremos a convergência nada fortuita entre, por um lado, os modelos de autoridade narrativa constitutivos do romance e, por outro, uma complexa configuração ideológica subjacente à tendência imperialista (Said, 1995, p. 108).
}

Assim, o modelo "Coração das trevas" servirá de fio condutor para esse fino projeto de crítica cultural, sendo o nome de Conrad, sem sombra de dúvida, o mais mencionado em todos os ensaios que compõem esse trabalho de Said.

No entanto, é o próprio autor que levanta suspeitas sobre essa visão tão cerrada do profundo viés ideológico da novela conradiana. Em mais de uma ocasião, o crítico deixa entrever o caráter ambíguo da obra-prima do escritor polonês, as facetas nebulosas das artimanhas construtivas da narrativa e da própria situação específica do autor, quando, por exemplo, assevera: "Por nunca ter sido um inglês totalmente incorporado e aculturado, Conrad preservou uma distância irônica em todas as suas obras" (Said, 1995, p. 57). 
A honestidade intelectual de Said e sua inconteste sensibilidade literária chegam mesmo a balançar as conclusões a que ele almeja, ao avaliar a novela de Conrad como uma "obra de imensa influência, tendo gerado muitas leituras e imagens", em que temos "uma África politizada, ideologicamente saturada que, para alguns objetivos e finalidades, era o lugar imperializado, com esses múltiplos interesses e ideias furiosamente em ação, e não um simples 'reflexo' fotográfico literário" (Said, 1995, p. 122, itálicos nossos). E vai completar o raciocínio de uma forma que nos interessa particularmente aqui, "a narrativa de Conrad está em grande parte preocupada com aquilo que escapa à expressão articulada - a selva, os nativos temerários, o grande rio, a obscura, grandiosa e inefável vida da África" (Said, 1995, p. 263). Apesar disso, o intelectual palestino mantém o tom assertivo e fulmina a obra literária como a mais firme apologia do colonialismo britânico:

embora deva-se notar que ficções como Coração das trevas são elaboradas de forma tão refinada pelos autores, e lidas com tanto cuidado pelo público para atender às exigências da narrativa, que elas ingressam de forma altamente especializada na luta pela África (Said, 1995, p. 123).

Nossa intenção aqui é colocar um grano salis na interpretação elaborada por Said, não para enfraquecer ou negar sua crítica cultural ao imperialismo, mas sim no sentido de ampliar seu escopo e mostrar que a ambiguidade que ele mesmo aponta ao dissertar sobre Conrad pode conduzir a uma leitura ainda mais instigante da obra maior do romancista polonês, pois, como Said mesmo enfatiza em seu ensaio, um "texto tão híbrido, impuro e complexo requer uma atenção especialmente aguda para ser interpretado" (SAID, 1995, p. 123).

Uma situação muito semelhante ocorre do outro lado do espectro de prestígio das línguas europeias, e na mesma época de Conrad: escrevendo em português, Eça de Queirós produz uma obra cujo caráter "híbrido, impuro e complexo" ainda hoje desconcerta leitores e críticos, e produz uma miríade de interpretações conflitantes e, muitas vezes, desabonadoras para o criador de $A$ ilustre casa de Ramires, romance em causa neste trabalho.

Publicado postumamente, pouco antes da edição em livro de $O$ coração das trevas, por volta de 1900, A ilustre casa de Ramires teve um destino funesto durante a ditadura salazarista. Cooptado juntamente com $A$ cidade e as serras (também póstumo, 1901), a obra passou a representar os ideais nacionalistas e coloniais do regime autoritário, sendo lida como uma apologia às tradições lusitanas, ao arcaísmo rural de sua vida interiorana e ao esforço ultramarino.

A reação da esquerda portuguesa foi mais política do que literária, e ela passou a ver as obras finais de Eça como inferiores e, de certa forma, traidoras dos 
pendores críticos e socialistas da primeira fase do autor. Testemunho dessa má vontade em relação à produção do que se convencionou chamar de Último Eça, o estudo de António José Saraiva, As idéias de Eça de Queirós (1982 [1a. ed. 1946], que poderia ser muito mais adequadamente intitulado de "A falta de idéias de Eça de Queirós"), decreta:

\footnotetext{
Ora destes dois elementos - a idéia expressa e a expressão da idéia, o tema e a forma, — só o segundo é inteiramente de Eça; quanto ao outro - idéias para exprimir, temas para realizar — vai buscá-los, ele que é um artista e não um filósofo, um estilista e não um poeta — onde? [...] É provável [...] que Eça de Queiroz seja o representante e o intérprete de certo número de idéias coletivas, quero dizer correntes em determinada época num determinado meio (Saraiva, 1982, p. 20).
}

Assim, o pensamento progressista entre os estudiosos de Eça salvava o beletrista, e jogava as ideias e valores desenvolvidos em sua ficção na conta de "outros": "em resumo é um estilista; vale pela fórmula nova que encontrou para idéias correntes" (Saraiva, 1982, p. 18). Mesmo o brasileiro Antonio Candido, em seu importante ensaio "Entre campo e cidade" (1964), profere a mesma sentença:

A dialética insidiosa do atavismo levou-o, pouco a pouco, a se acomodar numa visão mais puramente literária do romance, a "fazer estilo" demasiado ostensivamente, pondo de lado o sentido pragmático, de luta, dos primeiros livros (Candido, 1964, p. 53).

A situação muda ao final do século XX, com novos estudos e abordagens da fase final de Eça, mas o estrago já estava feito e a imagem reacionária e colonialista do escritor permanece em setores importantes da intelectualidade e entre os leitores. Numa conversa informal com pesquisadores dos estudos de literaturas africanas de língua portuguesa na USP, São Paulo, propus a possibilidade de uma leitura não colonialista de $A$ ilustre casa, e o descrédito dos colegas foi total.

A fim de dar conta do propósito de ampliar a leitura dos dois autores em questão, trago para este exame os preciosos insights do filósofo italiano Giorgio Agamben, em especial os conceitos da "inapreensibilidade" e da "narrativa do horror".

O Prefácio ao livro Estâncias do filósofo italiano Giorgio Agamben (1977 [ed. brasileira de 2007a]) talvez seja um momento ímpar em sua obra, pois, no afã de fornecer um fio condutor que ligasse os quatro ensaios que compõem o livro, autônomos e escritos em diferentes momentos, o autor acabou por oferecer com certa clareza (algo raro em seus escritos) algumas chaves do seu pensamento como um todo. Uma dessas chaves, que ele mesmo atribuiu ao grupo de Jena, nos esclarece sobre o papel de uma obra crítica e, portanto, do que devemos esperar e procurar nos ensaios que ele está nos apresentando: "Uma obra que merecesse ser 
qualificada como crítica só podia ser aquela que incluísse em si mesma a própria negação e cujo conteúdo essencial fosse assim exatamente aquilo que nela não se encontrava" (Agamben, 2007a, p. 9).

Creio ser mais do que justificável aceitar o desafio aí implícito e tentar uma possível resposta acerca do "conteúdo essencial" dos quatros ensaios, mesmo correndo o risco de uma resposta parcial ou mesmo enviesada. Para tanto, façamos uma breve análise estrutural do Prefácio. Nele podemos perceber que o filósofo italiano compôs uma moldura para seu texto que nos oferece uma pista bastante interessante. No início da seção, o primeiro período abre com uma referência ao gênero romance no mínimo enigmática:

De um romance é possível aceitar, em último caso, que não seja contada a história que nele devia ser contada; mas de uma obra crítica, pelo contrário, costuma-se esperar resultados ou, no mínimo, teses a demonstrar e, como se diz, hipóteses de trabalho (Agamben, 2007a, p. 9).

No fecho do Prefácio, ele retorna ao mesmo exemplo, agora individualizado numa referência clássica:

\footnotetext{
Assim, as páginas que se seguem pretendem apresentar-se como uma primeira e insuficiente tentativa, nas pegadas do projeto que Musil havia confiado ao seu romance incompleto e que, alguns anos antes, a palavra de um poeta havia expresso na fórmula segundo a qual "quem apreende a máxima irrealidade, plasmará a máxima realidade" (Agamben, 2007a, p. 15.).
}

Ora, os quatro ensaios de Estâncias falam de uma multidão de temas, que vão desde a poesia provençal e a reflexão medieval a respeito da melancolia, até o fetichismo da mercadoria formulado por Marx e o estudo do fetichismo como perversão feito por Freud (passando ainda pelo mito de Édipo e uma instigante análise do silêncio de Saussure), mas em nenhum momento o texto de Agamben aborda o romance moderno como objeto de análise, fazendo tão somente referências en passant. Conforme Claudio Oliveira (2008) nos mostra num estudo sobre Agamben, "o verdadeiro interlocutor de um filósofo não são outros filósofos, mas sempre um poeta" (Oliveira, 2008, p.110), podemos então inferir que talvez o principal interlocutor de Estâncias seja aquele poeta que escreve romances, em específico, os romancistas ditos modernistas, como nos aponta a rápida, mas aguda, alusão a Musil.

$\mathrm{Na}$ moldura inicial, Agamben sublinha uma possibilidade romanesca, a de não narrar a história que devia ser narrada, que imediatamente nos remete aos experimentos das vanguardas do começo dos Novecentos. Enquanto que a segunda moldura nos indica precisamente o romance-ensaio, cuja principal realização pode ser designada sem medo de errar como sendo $O$ homem sem qualidades 
(em alemão: Der Mann ohne Eigenschaften, de 1930, 33 e 43). Se for assim, o conteúdo essencial dos ensaios de Estâncias, que não está dentro deles, talvez se encontre nos romances-ensaios a la Musil. A proposta de fundo deste trabalho é, portanto, patrocinar uma interlocução entre Agamben e os dois romancistas mencionados na introdução que, segundo minha visão, prestimanearam com o romance-ensaio, ou ao menos com características deles, para executar uma tarefa impossível: narrar o horror. Para tal tarefa, seria fundamental tratar um pouco do pensamento de Agamben e de algumas se suas ideias seminais.

\section{O inapreensível agambeniano}

Antes, no entanto, é necessária uma nota de advertência. A tentativa de expor e explicar o pensamento de Agamben esbarra num problema razoável. O filósofo desconfia da linguagem e do pensamento que foram formatados pela metafísica ocidental, os quais, por sua própria natureza e visão de mundo dela decorrente, levam a uma compreensão enviesada da realidade humana. Tal posicionamento não é uma exclusividade sua, sendo compartilhado por outros pós-estruturalistas e até mesmo por pensadores de outras linhas, como, por exemplo, Theodor Adorno. Por isso, em sua escrita, nosso filósofo lança mão de recursos estilísticos e retóricos que, como aludi antes, torna seu discurso um tanto hermético (ver, entre outros, Pucheu, 2008, p. 57-8; e Sedlmayer, 2011), procurando assim vencer os constrangimentos linguísticos presentes no discurso ocidental.

Portanto, tentar explicar, sintetizar, as ideias de Agamben dentro dos padrões discursivos comuns à escrita acadêmica incorre no grande risco de deturpar esse pensamento exatamente pela forma - uma das coisas mais caras ao pensamento do filósofo italiano. Em minha defesa, acredito na necessidade de certa didática que faça a transição da linguagem e pensamentos passados para os novos meios intelectivos propostos por pós-estruturalistas e pós-modernos. Algo como aprender outra língua, processo que, em seu início, exige que o novo idioma seja decodificado nos termos da língua falada, para gradativamente ir se autonomizando e possibilitando seu uso de acordo com a sintaxe e o léxico demandados pela língua em aprendizagem. No caso da filosofia agambeniana acontece o mesmo: se não se encontrar um método didático que faça a transição entre as duas linguagens, fatalmente seu pensamento ficará circunscrito ao grupo de iniciados que tiveram a possibilidade de refazer o longo percurso que a atual geração de filósofos precisou trilhar a fim de atingir a nova intelecção.

Dito isto, e aproveitando a deixa, seria possível então afirmar que, numa nova versão do método cartesiano, Agamben exerce uma desconfiança hiperbólica ou sistemática. O afeto que o move, diferentemente de Descartes, não é a dúvida, 
mas sim a desconfiança: ele desconfia das escolhas tomadas na origem do nosso pensamento, o ocidental; desconfia da metafisica que este produziu; desconfia da linguagem e, mais além, da forma como usamos e como entendemos a linguagem; desconfia das interpretações que reflexões radicais feitas por luminares da filosofia, desde a Antiguidade, receberam no decorrer dos séculos, as quais fecharam nosso entendimento para caminhos mais produtivos de compreensão e da atuação na realidade.

A origem dessa desconfiança está em sua concepção messiânica da história. $\mathrm{Na}$ trilha aberta por Walter Benjamin, ${ }^{1}$ o filósofo italiano entende que a condição atual da humanidade e de sua ação no mundo é fruto de uma queda original, um erro perpetrado pelos homens no início da nossa civilização e cujos desdobramentos foram causadores das catástrofes que já conhecemos e de um muito provável desfecho trágico de nossa espécie num futuro não distante. $\mathrm{O}$ pecado originário, longe de haver sido uma desobediência a um deus vingativo, tem mais a ver com uma escolha desafortunada, que a princípio pareceria ser acertada, mas que, uma vez tomada, revelou-se um processo crescente, e até hoje sem volta, de ruína. ${ }^{2}$

No Prefácio a Estâncias, um desses momentos de queda é descrito como sendo a ruptura entre a filosofia e a poesia, "entre palavra poética e palavra pensante", uma cisão ligada "tão originalmente à nossa tradição cultural que já no seu tempo Platão podia declará-la "uma velha inimizade"" (Agamben, 2007a, p. 12). Dessa ruptura deu originem a uma cultura por assim dizer esquizofrênica, onde o pensamento rigoroso é capaz de conhecer seu objeto, mas não possuí-lo, ou gozá-lo - conforme prefere Agamben - ; enquanto a linguagem artística pode gozar seu objeto sem o conhecer. Conforme a lógica messiânica, essa fratura poderá ser sanada no futuro, ${ }^{3}$ quando uma nova sociabilidade tiver lugar - a utopia que nosso autor chamou de "a comunidade que vem" em seu livro homônimo (Agamben, 1993).

Enquanto isso não acontece, é papel de um pensamento verdadeiramente crítico denunciar essa ruptura, mas não para superá-la e, sim, como uma espécie de "terceira via", para, ao mesmo tempo em que delata a cisão entre poesia e filosofia, propor a tarefa mais árdua que cabe ao espírito humano, a "impossível tarefa de se apropriar daquilo que deve, de qualquer modo, continuar inapreensível" (Agamben, 2007a, p. 14).

1. Em particular "Sobre o conceito da História" (Benjamin, 1985, p. 222-32).

2. "Onde nós vemos uma cadeia de acontecimentos, ele [o anjo da história] vê uma catástrofe única, que acumula incansavelmente ruína sobre ruína e as dispersa a seus pés. Ele gostaria de deter-se para acordar os mortos e juntar os fragmentos" (Benjamin, 1985, p. 226).

3. Para Agamben, alguns poetas e filósofos modernos têm apontado para a superação dessa cisão, como Hölderlin e Nietzsche, que "são aqui chamados a testemunhar a urgência para que a nossa cultura volte a encontrar a unidade da própria palavra despedaçada" (Agamben, 2007a, p. 13). 
Para se compreender melhor a relação entre crítica e inapreensibilidade no pensamento agambeniano, devemos retomar por completo uma citação de Kant que nosso filósofo usou, bem no início do Prefácio (Agamben, 2007a, p. 9), de forma cifrada e fragmentada:

\begin{abstract}
Percorremos até agora o país do entendimento puro, examinando cuidadosamente não só as partes de que se compõe, mas também o medindo e fixando a cada coisa o seu lugar próprio. Mas este país é uma ilha, a que a própria natureza impõe leis imutáveis. É a terra da verdade (um nome sedutor), rodeada de um vasto e tempestuoso oceano, verdadeira sede da aparência (des Scheins) onde muita neblina e muito gelo, a ponto de se derreterem, dão a ilusão de novas terras, e constantemente ludibriam, com falazes esperanças, o viajante que sonha com descobertas. (Kant, 1994, p. 257.)
\end{abstract}

Não por acaso, a obra de onde se extrai esse trecho se vincula à esfera da crítica (Crítica da razão pura). Kant, nesse livro, traça os limites da razão humana e decreta que o conhecimento total é impossível. Para além do que podemos saber ("a ilha da verdade"), existe um universo insondável, que podemos vislumbrar, mas não atingir (a "sede das aparências"). Se para o epistemólogo alemão tal constatação se configura, então, como uma advertência para não se prosseguir por aí, pois a frustração é o prêmio que espera pelo "viajante que sonha com descobertas", para Agamben se trata de um convite irrecusável.

Segundo meu entendimento, pode-se dizer que, no pensamento de Agamben, caberia à esfera da ciência aquilo que se pode conhecer, ao apreensível - conforme os limites kantianos - , enquanto a filosofia deveria ser responsável por tentar ampliar os limites do apreensível, trabalhando sempre nos extremos do conhecimento, flertando com o abismo do insondável. No entanto, a malfadada cisão entre o poético e o filosófico inibe tal vocação, cabendo hoje à crítica a "investigação sobre os limites do conhecimento, sobre aquilo que, precisamente, não é possível nem colocar nem apreender" (Agamben, 2007a, p. 9).

A atividade crítica, entretanto, não pode, em sua busca ao inapreensível, se valer nem dos métodos científicos nem dos filosóficos (traídos que estão por uma metafisica equivocada), sem dizer de uma linguagem que se esvaziou de suas possibilidades também naquela queda original - conforme indicado acima na alusão à "desconfiança agambeniana". Para cumprir sua função, a crítica deve proceder como a arte da modernidade, que abdicando da característica de ser criativa, ela oferece hoje a sua negatividade, "a crítica se identifica hoje de fato com a obra de arte [moderna] [...] por ela também ser negatividade. Ela não é senão o processo da sua irônica autonegação" (Agamben, 2007a, p. 10).

A negatividade é outro conceito muito caro a Agamben e que pode, numa certa simplificação, ser entendido nas esferas da produção intelectual e artística como não entregar aquilo que se espera, ou seja, ao negar a tradição à qual a 
obra deveria estar ligada, ao romper com os padrões culturais que se esperariam encontrar naquele gênero, ao burlar as expectativas estéticas e filosóficas atualmente aceitas, ${ }^{4}$ a obra do pensador ou do poeta deixa escapar o objeto ao qual o público acreditaria ser a sua finalidade, e oferece o seu negativo, ou o nada: "O que fica fechado na "estância" da crítica é nada, mas esse nada contém a inapreensibilidade como o seu bem mais precioso" (Agamben, 2007a, p. 13). Como se pode perceber, voltamos ao início deste trabalho, quando nos perguntamos sobre aquilo que não se encontrava nos quatro ensaios de Estâncias.

Afirma ainda Agamben que, "assim como toda autêntica quête [busca], a quête da crítica não consiste em reencontrar o próprio objeto, mas em garantir as condições da sua inacessibilidade" (Agamben, 2007a, p. 11). É mais ou menos inevitável que o leitor desse filósofo se faça a pergunta fatal: o que se ganha com todo esse contorcionismo intelectual, onde se chega quando o ponto final é o inapreensível, ou o nada? Por sorte, o Prefácio nos concede uma resposta das mais instigantes:

Se uma convicção sustenta tematicamente essa indagação no vazio em que a sua intenção crítica a obriga a ficar, é precisamente porque só se formos capazes de entrar em relação com a irrealidade e com o inapreensível como tais, será possível apropriarmo-nos da realidade e do positivo (Agamben, 2007a, p. 15.)

Assim, define-se o objetivo maior dos ensaios de Estâncias, que na citada moldura final do Prefácio, o autor empresta, até onde sabemos, de Rilke: "Quem apreende a máxima irrealidade, plasmará a máxima realidade” (Agamben, 2007a, p. 15). Nos textos que se seguem, Agamben fará então uma arqueologia de vários objetos da cultura e da sociedade humana, em busca de mapear esse (não-) método de abraçar o inapreensível, a irrealidade, o nada. Para nossos objetivos aqui, acreditamos ser suficiente abordar rapidamente um dos mais significativos no livro.

A finalidade do primeiro ensaio de Estâncias, e que vai reverberar pelos outros três ensaios do livro, é a interpretação da gravura Melancolia I de Dürer, um dos maiores pintores e desenhistas do século XVI. A obra, que deveria ser parte de um tríptico que acabou não realizado, tornou-se uma das imagens mais estudadas e discutidas na cultura ocidental. Seu caráter enigmático e a abundância de símbolos e alegorias transformaram o desenho num verdadeiro quebra-cabeça intelectual.

4. “... a arte deveria renunciar às garantias que lhe provinham da sua inserção em uma tradição, pela qual os artistas construíam os lugares e os objetos nos quais se realizava a incessante soldagem entre passado e presente, entre velho e novo, a fim de fazer da própria auto negação a sua única possibilidade de sobrevivência" (Agamben, 2007a, p. 75-6). 
Agamben vai deixar de lado toda essa profusão simbólica e se concentrar no título da gravura, buscando na Antiguidade, Idade Média, Renascença e na psicanálise as várias definições e usos do conceito, a fim de realizar a arqueologia desse estado de espírito, também percebido como vício, doença e possessão. Em vez de uma melancolia, ele descobre duas: a acídia e a doença atrabiliária, ou a melancolia propriamente dita, que no decorrer da história acabariam se confundindo e se fundindo na melancolia como era conhecida na época de Dürer.

Entre os principais conceitos ou estruturas mentais/espirituais que configuram a melancolia, destaca-se o processo da perda de um objeto muito importante ou amado, que de fato não existe ou é inacessível, e sua conversão num objeto perdido - como se tivesse sido real —, sobre cujo fantasma (imagem mental que o melancólico projeta na realidade) é investida a libido, mas num processo conflituoso de amor e ódio.

A explicação da gravura fica assim: o anjo principal seria o artista (o gênio) cuja expressão representa sua fixação no fantasma do objeto inapreensível. Os objetos à volta seriam as marcas da realidade da qual ele abre mão para a contemplação e gozo do inacessível. Por fim, essa seria a própria condição da arte e o propósito da cultura, ligar o homem ao que há de mais importante e desfrutável: a posse do que não pode ser apropriado:

\footnotetext{
O anjo que medita não é, segundo uma interpretação já tradicional, o símbolo da impossibilidade da Geometria, e das artes que nela se fundamentam, de alcançar o incorpóreo mundo metafísico, mas, pelo contrário, é o emblema da tentativa do homem, no limite de um risco psíquico essencial, de dar corpo aos próprios fantasmas e de tornar predominante, em uma prática artística, aquilo que, do contrário, não poderia ser captado nem conhecido (Agamben, 2007a, p. 55-6).
}

Portanto, toda a parafernália simbólica que compõe a gravura, longe de exigir uma explicação individualizada para, depois, se chegar a uma interpretação totalizadora, configuraria na verdade os objetos de um "luto" virtual,

\footnotetext{
O compasso, a esfera, a mola, o martelo, a balança, a régua, que a intenção melancólica esvaziou de seu sentido habitual e transformou em emblemas do próprio luto, já não significam nada mais que o espaço que eles tecem para a epifania do inapreensível (Agamben, 2007a, p. 55-6).
}

Numa síntese preliminar do que discutimos até o momento, poderíamos dizer que, para além do que podemos saber, existe o tal "vasto e tempestuoso oceano", que podemos pressentir mas não tocar. Mais: temos o desejo de compreender esse insondável e tiramos prazer da nossa tentativa frustrada, da qual nos apossamos do que nos escapa através de sua própria ausência. A arte seria, assim, uma espécie de portal para o inapreensível, que possibilita seu vislumbre e permite desvios 
altamente $\neg$ reveladores. É na busca do inapreensível, da negatividade, que se tornam mais claros os contornos da realidade humana.

O que desejo propor agora, mais do que uma simples aplicação direta das ideias agambenianas aos estudos literários, é um confronto entre esse pensamento e duas obras ficcionais que estariam próximas do romance-ensaio, conforme ele se delinearia no século XX. Algo que poderia, então, servir de diálogo entre a filosofia e a literatura, conforme proposição já registrada no início deste trabalho, bem como tornar um pouco mais concreta uma reflexão tão abstrata como é a filosofia de Agamben.

Nossos dois escritores, como é sabido, são originários da periferia europeia e, nos estertores do século XIX, abordaram a questão da neocolonização africana por meio de formas literárias incomuns, forjando assim obras de grande originalidade. O polonês Joseph Conrad, por escrever em inglês (língua geral do Ocidente), teve a grande felicidade de tornar sua novela $O$ coração das trevas (de 1902, conforme já foi dito, mas publicada antes na Blackwood's Magazine, em 1899), uma das obras-primas da literatura oitocentista, cuja poderosa repercussão se faz sentir ainda em nossos dias. Menos feliz foi nosso Eça de Queirós com seu extraordinário romance $A$ ilustre Casa de Ramires, que permanece sendo uma referência na literatura de língua portuguesa, mas que dificilmente ultrapassa suas fronteiras.

Ambos os romances se utilizam, de modo muito significativo, da estratégia estético-literária denominada mise en abîme, na qual uma ou várias narrativas são encaixadas dentro de uma narração originária. A análise que proponho para semelhante estratagema artístico apresenta vários pontos de contato com o "inapreensível" agambiano, sendo que a articulação dessas duas vertentes especulativas parece resultar numa interpretação e ressignificação das obras ficcionais de grande potencial tanto do ponto de vista literário quanto do esforço de compreensão e denúncia do empreendimento colonial oitocentista.

A estrutura em mise en abîme (cf. Gide, 1992), ou em narrativas encaixadas (cf. Todorov, 2006), é uma forma de composição artística muito antiga, sendo utilizada, ainda, nas artes plásticas, no teatro e cinema, além de comum na publicidade. Na literatura, ela pode ser reportada aos diálogos platônicos, mas o clássico mais conhecido em sua utilização são as Mil e uma noites, razão pela qual Todorov lança mão de inúmeros exemplos retirados dessa obra em seu fundamental Estruturas narrativas (2006, p. 119-33). A mise en abîme literária define-se como uma ou mais narrativas dentro de uma narração originária, que as contém, causando um efeito de espelhamento e projeção ao infinito de grande poder significativo e representacional. 


\section{Conrad à luz do inapreensível}

Em $O$ coração da trevas, a narrativa originária tem por enunciador um marinheiro anônimo, membro da equipagem do iate Nellie, que se encontra ancorado no Tâmisa à espera de ventos. Esse narrador, com certo desconforto, nos conta então uma aventura de um colega, Marlow, marujo experiente e muito viajado, mas o faz relatando as próprias palavras do companheiro, abrindo assim uma segunda narrativa que, com algumas breves interrupções, comporá a novela até o final do livro, quando então volta à primeira narração, fechando assim o livro. Já dentro da narrativa de Marlow, teremos ainda alguns momentos em que outra narrativa e outro narrador se formam. É o caso de um jovem aventureiro russo, semienlouquecido no trabalho de colono, responsável pela narração de alguns momentos reveladores a respeito de Kurtz, um capataz de uma companhia belga que explora o marfim no interior do Congo, África.

Portanto, Marlow relata a história central do livro, que basicamente se resume à viagem que ele comanda num pequeno navio pelo rio Congo, até uma região pouco conhecida da selva centro-africana, para resgatar o tal Kurtz, que se achava muito doente e, possivelmente, ensandecido. Aos poucos, durante a narrativa, o leitor vai sendo fragmentariamente informado sobre o capataz: um europeu culto, pintor, músico, amante da literatura, de sofisticada formação, que vai ao Congo fazer riqueza. Estabelecendo-se nos limites do território conhecido, ele se transforma no maior fornecedor de marfim da região através de métodos incógnitos para seus colegas e superiores.

Marlow, que não o conhecia, vai formando uma imagem quase mítica de Kurtz, seduzido e seduzindo os leitores pelos relatos de personagens secundários, como o do jovem russo. Quando finalmente Marlow resgata Kurtz, este morre pouco depois sem fazer a narrativa que tanto seu "salvador" quanto nós leitores aguardávamos com ansiedade: a sua história no coração das trevas.

Atalhando bastante a análise, a narrativa que não é feita deveria nos revelar como um europeu hipercivilizado se transformou num deus primitivo, em meio a um povo "bárbaro", e de como, através da extrema violência, obteve não apenas o sucesso comercial mas uma experiência sobre-humana (ou inumana), cuja felicidade, ou prazer, decorrente o impediu contra todo o bom senso de retornar à Europa. Nos termos propostos pela própria novela, se trataria de narrar "o horror, o horror", últimas palavras proferidas por Kurtz.

A narração do horror e a questão do estado de exceção, dois elementos fundantes da novela de Conrad, fazem parte também dos interesses de Agamben, cuja relação com o escritor Primo Levi o levou a se debruçar sobre a Shoah (denominação mais adequada do que Holocausto) e o problema do testemunho, 
única forma possível de representação para o registro do horror dos campos de concentração nazistas (ver Agamben, 2008).

Conrad que foi também testemunha do horror da neocolonização africana, apesar de não ter sido vítima (ao menos não vítima central), parece ter constatado a impossibilidade dos meios expressivos tradicionais para fazer sua representação. Por meio da estratégia das narrativas encaixadas, o escritor polonês consegue aquilo que Agamben considera o papel da obra crítica: construir sua negação e jogar seu conteúdo essencial para fora do próprio texto. A novela não narra o que deveria ser o seu objeto, mas é capaz de fazer o leitor vislumbrar esse inapreensível, "o horror, o horror".

Através de um infernal jogo de espelhos, a novela vai transferindo para a consciência do leitor a formulação, mesmo que impossível, da história de Kurtz. Com os reflexos que as narrativas encaixadas vão projetando sobre o leitor, este é capaz de vagamente pressentir o fantasma que assume o locus da não-narrativa do capataz. Um desses momentos, o mais ofuscante (que ilumina mas cega), é certamente o da chegada de Marlow ao Congo. Na subida até a sede local da empresa que o contratara, o marinheiro tem a experiência do cemitério de mortos vivos:

\footnotetext{
Vultos negros encurvados jaziam, sentados entre as árvores recostados em seus troncos, agarrando-se à terra, meio visíveis meio ocultos naquela claridade baça, em todas as atitudes de dor, abandono e desespero. Outra mina explodiu no rochedo seguida de um leve estremecimento do solo embaixo dos meus pés. $\mathrm{O}$ trabalho prosseguia. $\mathrm{O}$ trabalho! E aquele era o lugar para onde alguns auxiliares haviam se retirado para morrer. Eles estavam morrendo aos poucos - isso ficou muito claro. Não eram inimigos, não eram criminosos, não eram nada de real agora - nada além de sombras negras de doença e inanição jazendo em confusão na penumbra esverdeada. Trazidos de todos os recessos da costa com toda a legalidade de contratos temporários, largados em ambientes insalubres, alimentados com uma comida nada familiar, eles adoeciam, ficavam imprestáveis e tinham então a permissão para se arrastar para longe e morrer. Esses vultos moribundos eram livres como o ar - e quase tão tênues como ele (Conrad, 2004, p. 29-30).
}

A cena ocorre antes da primeira menção a Kurtz na novela, numa espécie de anticlímax, já que a aventura central mal havia começado. Ela contraria, portanto, a boa lógica de um enredo, que destina os momentos de maior contundência para próximo ao desfecho da história. É como se Conrad, ciente da impossibilidade de narrar o horror, oferecesse ao leitor apenas o resíduo dele, o resultado macabro da catástrofe que o empreendimento neocolonial produzia na África. Agamben, sem dúvida, teria aqui um excelente espécime da representação literária daquilo que ele chamou de "vida nua", conceito desenvolvido a partir da biopolítica formulada por Foucault (cf. Agamben, 2004).

Enfim, a novela que se nega a si mesma, desdenhando do artesanato próprio do gênero, e se dobrando sobre si própria, num movimento discursivo típico do 
romance-ensaio - conforme antecipamos pouco acima - cria o espaço necessário para o salto em direção ao inapreensível. O texto de Conrad se configura como o não-signo da narrativa que não pode ser expressa. ${ }^{5}$

\section{Eça à luz do inapreensível}

Se a novela de Conrad pode ser considerada como exemplar da quête pelo inapreensível, o caso de $A$ ilustre Casa de Ramires, de Eça de Queirós, se mostra ainda muito mais complexo e intricado. Mais do que narrativas encaixadas, essa obra oferece uma das formulações mais bem-acabadas do romance-dentro-do-romance da literatura ocidental. A narrativa originária é o romance realista sobre o aristocrata aburguesado Gonçalo Ramires, que, no desenvolvimento do enredo, escreve uma novela histórica, à moda romântica, sobre Tructesindo Ramires, um de seus antepassados medievais. Apenas por este resumo sumaríssimo já vemos emergir uma característica diferenciadora entre as duas obras analisadas: o uso da função-autor como elemento de composição ficcional.

A menção do conceito formulado por Foucault, e retomado por Agamben em Profanações (2007b), não é casual aqui. Segundo o filósofo francês, "em uma cultura como a nossa, há discursos dotados da função-autor, e outros que são desprovidos dela. [...] A função-autor caracteriza o modo de existência, de circulação e de funcionamento de certos discursos no interior de uma sociedade" (apud Agamben, 2007b, p. 50). Em outras palavras, a recepção do texto e sua interpretação dependem da relação que se faz entre o nome do autor e o contexto que este cria em torno da obra. No romance de Eça, isso é fundamental.

Pelo jogo de espelhamentos produzido pela mise en abîme, o leitor arguto vai percebendo a falsidade da novela histórica de Tructesindo que, de apologia à coragem e lealdade da antiga família feudal, mostra-se ironicamente como um exercício de arbítrio e violência, produzida por um autor interessado e instrumentado para obter vantagens com sua "obra literária". A mesma desconfiança, então dedicada à obra e ao autor da novela, deve recair sobre o romance realista e seu "autor", ou melhor, sobre a função-autor que dá sentido à narrativa originária — e que não deve se confundir com o sujeito Eça, autor de fato do livro.

Numa conclusão bastante sumária, a novela romântica e o romance realista são flagrados pela manobra literária de Eça como discursos ideológicos, cujos interesses inconfessáveis surgem em negativo no confronto entre as narrativas encaixadas. Mas o que esse recurso oferece como principal resultado é a projeção

5. “... cada coisa é ela mesma só na medida em que significa outra, cada coisa é verdadeira só se está para uma outra” (Agamben, 2007a., p. 227). 
de um romance elíptico, uma narrativa não escrita, mas que se oferece como negatividade dos textos concretos.

A violência extrema usada por Tructesindo para submeter o oponente (cena do flagelo de Lopo de Baião, em Queirós, 1999, p. 424-27) e a crueldade de Gonçalo contra o camponês que não se dobrava aos poderosos (cena da luta contra Ernesto de Nacejas em Queirós, 1999, p. 389) se projetam como métodos de exploração a serem usados no empreendimento colonial que Gonçalo realiza na África. Aqui, como na obra de Conrad, o mais interessante e instigante não é narrado, ou seja, o processo de enriquecimento astronômico que o protagonista consegue em quatro anos de exploração colonial africana. A obra de Eça se encerra com os preparativos de familiares e amigos para receber de volta Gonçalo, que não mais atua na história, mas paira virtualmente como um mito fundador (cf. a comparação feita entre Gonçalo e Portugal no fecho do romance).

Retomando Agamben, o funcionamento do jogo entre as duas narrativas tem paralelo com a explicação da gravura de Dürer dada pelo filósofo italiano: o romance histórico e o romance realista esvaziados "de seu sentido habitual" e transformados "em emblemas do próprio luto, já não significam nada mais que o espaço que eles tecem para a epifania do inapreensível" (Agamben, 2007a, p. 56, citado ao final da segunda seção deste ensaio), ou seja, do romance elíptico, que se projeta virtualmente como forma de narrar o horror do estado de exceção no sistema colonial africano do séc. XIX.

O texto elíptico, portanto, não deve ser escrito mentalmente pelo leitor, mas tão somente intuído por ele. E não apenas por se tratar de algo cuja totalidade não possa ser de fato apreendida pelo sujeito, mas que, além disso, deva ser mantida à distância, sob risco de queimar e destruir o leitor, a exemplo de Ícaro que se aproximou demais do sol e, por isso, sucumbiu. Ou, ficando dentro de nosso corpus, para não se dar conosco o mesmo que aconteceu com Kurtz!

O inapreensível se situa nessas obras dentro do campo psicanalista do Tânatos, mas não em sua fenomenologia individual e sim no seu caráter especifico, relativo à espécie humana. Indica-se no gesto dessas narrativas para o aquilo que há de mais destrutivo e incontrolável no caráter humano, na pulsão de morte que move não apenas o espécime mais toda a espécie. Algo que como a Medusa, destrói ao ser olhado e, por isso, precisa do escudo de Teseu para ser refletido, mas não apreendido.

No romance moderno, ou mais especificamente no chamado romance-ensaio, a história a ser contada não está lá - tudo o que a narrativa concreta faz 
de significativo é um gesto, ${ }^{6}$ uma indicação para um (não-)signo, um (não-)texto, uma outra (não-)obra, que existe na sombra da obra concreta, mas que esta propriamente não contém. Em O coração das trevas, os vários narradores gesticulam com seu contar para outras narrativas, as quais quanto mais se distanciam da narrativa originária, mas perto se aproximam do inumano, ou da irrealidade do humano. Em A ilustre Casa de Ramires cada "autor" gesticula com seu livro para outros livros, cujo limite é o romance que não pode se escrito, mas que habita à sombra do romance concreto.

\section{Referências}

Agamben, Giorgio. A comunidade que vem. Tradução de António Guerreiro. Lisboa: Presença, 1993.

Agamben, Giorgio. Homo sacer: o poder soberano e a vida nua I. Tradução de Henrique Burigo. Belo Horizonte: Ed. UFMG, 2004.

Agamben, Giorgio. Estâncias: A palavra e o fantasma na cultura ocidental. Tradução de Selvino José Assmann. Belo Horizonte: Editora UFMG, 2007a.

Agamben, Giorgio. Profanações. Trad. de Selvino José Assmann. São Paulo: Boitempo, 2007b.

Agamben, Giorgio. O que resta de Auschwitz: o arquivo e a testemunha: Homo Sacer III. São Paulo: Boitempo, 2008.

Benjamin, Walter. Magia e técnica, arte e política: ensaios sobre literatura e história da cultura. São Paulo: Brasiliense, 1985.

Candido, António. "Entre campo e cidade”. In: Candido, António. Tese e antitese. São Paulo, Nacional, 1964, p. 31-56.

Conrad, Joseph, O coração das trevas. Trad. Celso N. Paciornik. São Paulo: Iluminuras, 2004 [1902].

Gide, André. Journal 1889-1939. Paris: Gallimard, 1992.

Kant, Immanuel. Crítica da Razão Pura. Lisboa: Fundação Calouste Gulbenkian, 1994.

Oliveira, Claudio. A linguagem e a morte. In: Pucheu, Alberto (Org.). Nove abraços no inapreensivel: filosofia e arte em Giorgio Agamben. Rio de Janeiro: Beco do Azougue: FAPERJ, 2008, p. 101-132.

Pucheu, Alberto. Estâncias. In: Pucheu, Alberto (Org.). Nove abraços no inapreensível: filosofia e arte em Giorgio Agamben. Rio de Janeiro: Beco do Azougue; FAPERJ, 2008, p.45-73.

Queirós, Eça de. A ilustre Casa de Ramires. Edição Crítica das Obras de Eça de Queirós. Lisboa: Imprensa Nacional-Casa da Moeda, 1999.

Said, Edward. Cultura e imperialismo. São Paulo: Companhia das Letras, 1995.

6. "Se chamarmos de gesto o que continua inexpresso em cada ato de expressão, poderíamos afirmar então que, exatamente como o infame, o autor está presente no texto apenas em um gesto, que possibilita a expressão na mesma medida em que nela instala um vazio central" (Agamben, 2007b, p. 52). 
Sedlmayer, Sabrina. O pensamento crítico de Giorgio Agamben e sua contribuição para os estudos literários. Revista FronteiraZ, São Paulo, n. 7, dez. 2011. Disponível em: < http://www.pucsp. br/revistafronteiraz/download/pdf/estudos_Sabrina_Sed.pdf>. Acesso em: 10 abr. 2012.

Saraiva, António José. As ideias de Eça de Queiroz. Lisboa: Bertrand, 1982 [1946].

Todorov, Tzvetan. As estruturas narrativas. Tradução de Leyla Perrone-Moisés. São Paulo: Perspectiva, 2006. 